\title{
Parenting style, proactive personality, and career decision self-efficacy among senior
}

\section{high school students}

\author{
Melly Preston ${ }^{1}$, Rose Mini Agoes Salim ${ }^{2}$ \\ ${ }^{1,2}$ Faculty of Psychology, Universitas Indonesia, Indonesia \\ ${ }^{1}$ prestonmelly@gmail.com; ${ }^{2}$ romy.prianto@gmail.com
}

\section{ARTICLE INFO}

\section{Article history}

Received 31 December 2018

Revised 16 August 2019

Accepted 27 August 2019

Keywords

career decision self-efficacy parenting style

proactive

personality

\begin{abstract}
Making a career decision is one of the most complex development tasks faced by high school students who will graduate from school. Students need to believe that they would succeed in their effort to do the necessary tasks during the process of career decision-making. This belief is referred to as a career decision self-efficacy. This study examined the influence of parenting style on career decision self-efficacy through the mediation of proactive personality in senior high school students. A total of 949 participants were involved in this study. Data were collected using Career Decision Self-Efficacy Scale-Short Form, Parental Authority Questionnaire, and Proactive Personality Scale. Data were analyzed using the regression technique with the Macro Process from Hayes. The regression results show that fathers' and mothers' authoritative parenting directly affect career decision self-efficacy; fathers' and mothers' authoritarian parenting, as well as mother's permissive parenting, affect the career decision self-efficacy only through the mediation of proactive personality. Also, fathers' permissive parenting did not have a significant effect on career decisions self-efficacy either directly or indirectly through a proactive personality. Therefore parents - both father and mother - need to involve in developing career decision self-efficacy of their children through parenting process, especially authoritative parenting.
\end{abstract}

\section{Introduction}

Making a career decision is one of the most complex and challenging processes in life (Di Fabio, Palazzeschi, Asulin-Peretz, \& Gati, 2013), especially for senior high school students who will graduate soon. Based on the career development theory (Patton \& Porfeli, in Patton \& McMahon, 2014), senior high school students, who are in the stage of adolescence, are in the stage of career exploration that they have to find out about themselves. They need to explore various career possibilities, identify various career outcomes, and ultimately make career decisions. In the process, students need to consider many factors so that their decisions will lead to career success.

The complexity of the career development of senior high school students in Indonesia can be illustrated through the education system. High school students are directed to continue their education to a higher level (Depdiknas, 2004). As is known, there are hundreds to thousands of choices of majors and universities that are available in Indonesia (Dilas, Mackie, Huang, \& Trines, 2019). Before choosing, they must also consider the career fields they want to pursue and which are available in current employment, so that the chosen majors can be in line with their career choices. They are expected to be able to make the right decision because there is no stage of tryout or career exploration and counselling 
for first-year students who still have not made decisions, such as those provided by several universities in other countries. If they feel they have taken the wrong decision, then the choice is to drop out, preserve even though they do not like it, or move to other major and university, which is considered more appropriate but will cost time and money.

Those complexity makes many high school students face difficulties and confuse in making career decisions. A preliminary survey that conducted by authors on 65 high school students in Jakarta showed that almost half of them still have not chosen college majors, and many of those who had chosen college majors claimed that they still felt doubtful about their choices or decisions. This career indecision is a normal and positive development experience in the career exploration stage. However, it can lead to many undesirable impacts when it lasts too long (Marcionetti \& Rossier, 2016), such as less commitment to work. Based on this survey, high school students may need assistance during the process of making a career decision.

Previous research found that career indecision can be reduced or overcome by one of the factors referred to as career decision self-efficacy (CDSE) (Crişan \& Turda, 2015; Lent, Ezeofor, Morrison, Penn, \& Ireland, 2016; Penn \& Lent, 2016). CDSE is the individual's belief that they can successfully make career decisions through completing tasks needed in the process of making career decisions (Taylor \& Betz, 2006). These tasks are also conceptualized as competencies that must be acquired to be able to make the right career decisions. The five tasks or competencies are: self-appraisal, gathering occupational information, choosing goals, planning and problem-solving. CDSE is considered as a necessary factor in the process of making career decisions and developing one's career. Not only may reduce career indecision, CDSE also has a positive impact on many career-related factors, such as intention and career exploration behavior (Gushue, Scanlan, Pantzer, \& Clarke, 2006; Lent et al., 2016), career planning (Rogers \& Creed, 2011), and career success (Ballout, 2009).

Based on the Social Cognitive Career Theory, CDSE can be influenced by several factors (Lent \& Brown, 2013). Two factors that have significant influence on CDSE are contextual or environmental factors and personality factors. Of the many contextual and personality factors, parenting style and proactive personality are two factors that receive much attention in current studies (Kim \& Park, 2017; Lease \& Dahlbeck, 2009; Sovet \& Metz, 2014).

Parenting style is a collection of attitudes communicated by parents to children and which simultaneously create an emotional climate or atmosphere in which parenting behavior is expressed (Darling \& Steinberg, in Park, Kim, Chiang, \& Ju, 2010). Parenting style consists of three types, namely authoritative, authoritarian, and permissive (Baumrind, 2013). Authoritative parenting is characterized by two-way communication, behavioral control, demands for maturity, and warmth and responsiveness of parents to children's needs. Authoritarian parenting is characterized by behavioral and psychological control of children, emphasizes child obedience, and lacks warmth. Permissive parenting is characterized by high warmth and responsiveness of parents to the needs of children, but low in control and demands for maturity (Baumrind, 2013).

Among the three parenting style types, authoritative is the one most often found to have a positive impact on child development (Baumrind, 2013), including on children's career development (Ballout, 2009; Penn \& Lent, 2016; Rogers \& Creed, 2011); while authoritarian and permissive parenting tend to produce negative impacts on child development (Baumrind, 2013). However, in certain cultural contexts, especially East or 
Asian cultures, authoritarian parenting style is found to have a positive impact on children, including their CDSE. This result can occur because of differences in meaning associated with the behavior of authoritarian parents in Eastern cultural communities, where parental control is perceived as a form of caring, involvement, and parental care for children (Chao \& Tseng, 2002).

In Indonesian society, generally, fathers and mothers adopted different parenting style (Riany, Meredith, \& Cuskelly, 2017) and children can perceive these differences. A study conducted by Holmbeck et al. (cited in McKinney \& Renk, 2008), found that girls and boys tended to perceive their mothers as figures who formed supportive mutual relationships and showed more warmth than fathers. Meanwhile, children tended to perceive their fathers as authority figures who spent less time with them and give suggestions.

Many studies have examined the direct relationship between parenting and CDSE, but the mechanism that occurs between the two variables is still not explained. Fathers and mothers are significant others who continue to influence children as they go through important stages of development, such as going to school, puberty, and adolescence (Anaya \& Pérez-Edgar, 2019). These stages are the stages in which children explore self-identity and organize their social world, which in turn affects the child's personality development (Anaya \& Pérez-Edgar, 2019).

Brown and Hirschi (2013) stated that personality has several roles in the career development process. First, individuals tend to look for an educational and work environment that suits their personality, and that can strengthen their personality. Also, individuals also tend to shape their environment to better suit their personality.

Seibert, Crant, and Kraimer (1999) found that to achieve career success, it is necessary for individuals to be more proactive or have a high proactive personality. Proactive personality is a stable disposition towards proactive behavior or behavior that tends to influence the environment (Bateman \& Crant, 1993; Seibert et al., 1999). As Bateman and Crant (1993) explained, people with proactive personality are characterized by their active action to search for opportunities, show initiative, unconstrained by situational force, take part in changing their environment, and preserve until they can reach their goals. They also find and solve problems in order to reach their goals.

Proactive individuals tend to take the initiative to start the process earlier, so that they have more time to find information about their interests or make plans and also helps them to master skills or collect other things needed to make career decisions (Kim \& Park, 2017). Furthermore, proactive individuals tend to have high work performance (Crant, 1995) and able to adapt to their careers (Hou, Wu, \& Liu, 2014). Therefore, individuals who have a proactive personality may have high CDSE. Based on the explanation above, this study examined the effect of authoritative, authoritarian, and permissive parenting from mothers and fathers on CDSE through proactive personality as mediator among senior high school students.

\section{Method}

\section{Research Participant}

The participants were 949 senior high school students from three schools in Jakarta $(47.7 \%$ in 11 th grade, $52.3 \%$ in 12th grade), selected with convenience sampling. Among them $37.2 \%$ female and $62.8 \%$ male. Age ranged from 15 to 17 years old $(\mathrm{M}=16$ years old, SD 
$=$ one year old). Data collection was done after obtaining permission from the school and the students' informed consent. Participants were also informed that their identities were kept confidential and data would only be used for research purposes.

\section{Instrument}

CDSE was measured by Career Decision Self-Efficacy-Short Form (CDSE-SF; Taylor \& Betz, 2006) that have been adapted to Bahasa Indonesia by Sawitri (2009). CDSE-SF consists of 25 items divided into five subscales: Self-Appraisal, Gathering Occupational Information, Making Plans, Choosing Goals, and Problem-solving. Responses were obtained through 6 scale points that range from Very Unconfident (1) to Very Confident (6) which showed the participants' level of confidence that they were able to perform the tasks mentioned in each item. Kim and Park (2017) showed that CDSE-SF has high internal consistency reliability with Cronbach's Alpha $=.92$. In this study, the results of validity tests using Confirmatory Factor Analysis (CFA) and Corrected Item-Total Correlation (Crit) techniques indicated that 21 of the 25 items in the CDSE-SF are valid with factor loading ranges from .42 to .75 (t-value> 1.96) and the Crit score ranges from .407 to .630 . The Cronbach's Alpha score was .901. These results mean that CDSE-SF is a valid and reliable scale.

The Parental Authority Questionnaire (PAQ) designed by Buri (1991) was used to measure parenting style. We adapted the PAQ into Bahasa Indonesia through translate and back-translated process and the expert judgment (two lecturers and experts in Psychology of Human Development and Quantitative Research Method). PAQ consists of 30 items divided into three subscales to measure authoritative, authoritarian and permissive parenting style types. PAQ measured each parenting style separately between father and mother, so the overall items are 60 items. Responses were obtained through a 6-point Likert-type scale that ranges from 1 (Strongly disagree) to 6 (Strongly agree). The higher score in each subscale, the more the participants perceive their father or mother to adopt each parenting style measured by the subscale. Therefore, each participant will have score for authoritative, authoritarian, and permissive parenting for each of their father and their mother.

Abubakar, Van de Vijver, Suryani, Handayani, \& Pandia, (2015) showed that PAQ has high enough internal consistency reliability with Cronbach's Alpha for all the subscales was .70. In this study, based on the results of CFA and Crit, 41 items are valid to measure parenting style. In detail, nine items were valid to measure fathers' authoritative parenting, six items to measure fathers' authoritarian parenting, five items to measure fathers' permissive parenting, eight items to measure mothers' authoritative parenting, eight items to measure mothers' authoritarian parenting, and five items to measure mothers' permissive parenting. Overall, the loading factors ranges from .39 to .87 , Crit ranges from .298 to .718 , and the Cronbach's Alpha ranges from .632 to .885. These results indicate that the 41 items in PAQ are valid and reliable enough to measure parenting style in mothers and fathers. Therefore, the 41 items are used to measure parenting style in this study.

Proactive personality was measured by Proactive Personality Scale (PPS; Bateman \& Crant, 1993; Seibert et al., 1999). We adapted PPS into Bahasa Indonesia through translate and back-translated process and the expert judgment (two lecturers and experts in Educational Psychology, Career Development, and Quantitative Research Method). PPS was a unidimensional scale that uses 6-point Likert-type responses ranged from 1 (Strongly disagree) to 6 (Strongly agrees). A higher score indicates stronger proactive personality. Kim and Park (2017) also used PPS in their study and showed that PPS was a highly reliable instrument with the Cronbach's alpha obtained was .90 . Based on the results of the 
CFA test and Crit of PPS in this study, seven of the ten items are valid (factor loading $=.53$ - .75, $\mathrm{t}$ value $>1.96$, Crit $=.370-.583$ ). The Cronbach's Alpha was .762 , so it can be concluded that PPS is a reliable measuring instrument. Therefore, this study uses the remaining seven items to measure proactive personality.

In order to test the research hypothesis, we conducted correlation analysis to determine the correlation between research variables. Then we proceeded with regression and mediation tests using Macro PROCESS from Hayes (2013). The score used for analysis is the mean score of each scale or the research subscale.

\section{Results}

Based on the Pearson Correlation results shown in Table 1, the three parenting style from father and mother correlate positively and significantly with proactive personality. In fathers, authoritative parenting style have the highest correlation score with proactive personality $(\mathrm{r}=.254)$, while authoritarian parenting style have the lowest correlation score $(\mathrm{r}=.161)$. In mothers, authoritative and permissive parenting style have the same correlation magnitude $(\mathrm{r}=.193)$ that greater than authoritarian parenting style $(\mathrm{r}=.119)$. Result also shows that CDSE correlates positively and significantly with the three parenting style used by fathers. The strongest correlation was with the authoritative parenting style ( $\mathrm{r}$ $=.303)$, followed by permissive parenting style $(\mathrm{r}=.192)$, and authoritarian parenting style $(\mathrm{r}=.096)$. In mother, CDSE correlates positively and significantly with two types of parenting style adopted by mothers, namely authoritative and permissive. Authoritative parenting style has stronger correlation with CDSE $(r=.275)$ than the permissive parenting style $(r=.202)$.

CDSE also correlates positively and significantly with proactive personality with considerable correlation strength, which is equal to .541. These results indicated that the higher tendency of high school students to behave proactively, the higher their self-efficacy in making career decisions.

Table 1

Correlation Matrix between Variables

\begin{tabular}{lrrrrrrrr}
\hline Variabel & 1 & 2 & 3 & 4 & 5 & 6 & 7 & 8 \\
\hline$M$ & 4.47 & 3.66 & 4.27 & 4.71 & 3.80 & 4.46 & 4.42 & 4.60 \\
SD & .84 & .92 & .81 & .74 & .87 & .78 & .57 & .55
\end{tabular}

Father

1. ATV

2. ATN

3. PER

.03

Mother

4. ATV .42** .06* .23**

5. ATN $.09 * * \quad .53 * * \quad .00 \quad-.11 * *$

$\begin{array}{llllll}\text { 6. PER } & .20 * * & -.01 & .42 * * & .60 * * & -.25 * *\end{array}$

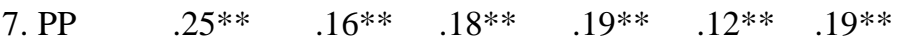

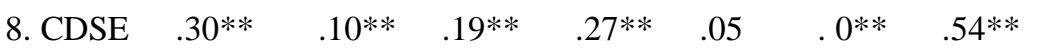

Note. $A T V=$ Authoritative, $A T N=$ Authoritarian, $P E R=$ Permissive, $P P=$ Proactive Personality, CDSE = Career Decision Self-Efficacy; $* p<.05 * * p<.01$ 
Fathers' Parenting Style, Proactive Personality, and CDSE

The regression analysis shows different results for the three types of parenting style. From Figure 1, we could see that proactive personality significantly influences CDSE ( $b=.463$, $p=.000)$. Authoritative parenting significantly influences proactive personality $\left(a^{l}=.124\right.$, $p=.027)$ and $\operatorname{CDSE}\left(c^{\prime l}=.079, p=.001\right)$. Based on the test results, we can observe that fathers' authoritative parenting also indirectly influenced CDSE $\left(a^{1} b=.057, p=.000\right)$. These results indicate that fathers' authoritative parenting can influence CDSE directly or indirectly through a proactive personality.

Authoritarian parenting also contribute significantly to proactive personality $\left(a^{2}=\right.$ $.071, p=.004)$, but not to $\operatorname{CDSE}\left(c^{\prime 2}=.008, p=.710\right)$ directly. In addition, fathers' authoritarian parenting significantly influence CDSE $\left(a^{2} b=.033, p=.005\right)$. This shows that authoritarian parenting can only affect CDSE indirectly through the proactive personality. Meanwhile, permissive parenting style does not contribute significantly to proactive personality $\left(a^{3}=.034, p=.259\right)$ and $\operatorname{CDSE}\left(c^{\prime 3}=.011, p=.662\right)$. It means that permissive parenting do not affect CDSE directly or indirectly through proactive personality.

\section{Descriptive Statistics}

The mean of the positive dimensions is higher than that of the negative dimensions (see Table 2). This trend applies in the calculation of all participants as one whole as well as per island. In all participants, the warmth dimension had the highest mean (3.43), and rejection has the lowest mean (1.99). The same pattern was found for participants in Java, Sumatera, Kalimantan, and Papua. In Sulawesi, structure has the highest mean, while rejection has the lowest mean. Rather contrasting to the other islands, the highest mean in Maluku belongs to autonomy support, and the lowest is chaos.

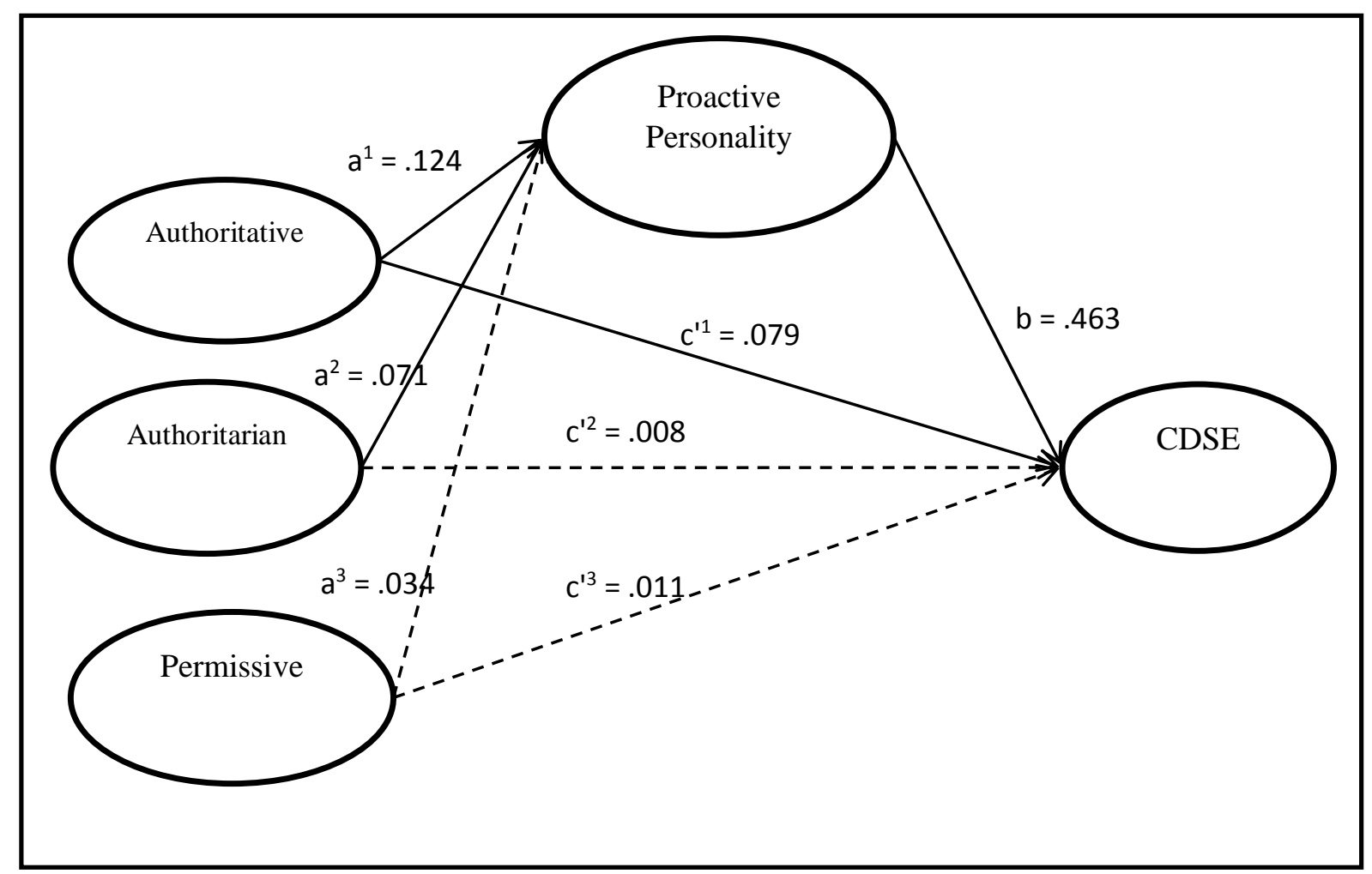

Figure 1. Model of the Effect of Fathers' Parenting Styles on CDSE through Proactive Personality 
Mothers' Parenting Style, Proactive Personality, and CDSE

Figure 2 show quite different results between the three types of mother parenting style. Mothers' authoritative parenting does not contribute significantly to proactive personality $\left(a^{1}=.017, p=.622\right)$, but contributed significantly to $\operatorname{CDSE}\left(c^{\prime l}=.094, p=.001\right)$. In addition, the indirect effect of maternal authoritative parenting on CDSE is insignificant $\left(a^{1} b=.008, \mathrm{p}=.623\right)$. These results indicate that proactive personality does not mediate the influence of mothers' authoritative parenting on CDSE.

In authoritarian parenting, this research found that authoritarian parenting contributes significantly to proactive personality $\left(a^{2}=.054, p=.040\right)$, but not to CDSE $\left(c^{\prime 2}=-.007, p\right.$ $=.753)$. The indirect effect of mothers' authoritarian parenting on CDSE occurs significantly $\left(a^{2} b=.025, p=.041\right)$. Permissive parenting contributes significantly to proactive personality $\left(a^{3}=.107, p=.002\right)$, but not to CDSE directly $\left(c^{\prime 3}=.000, \mathrm{p}=.998\right)$. The indirect effects of mothers' permissive style on CDSE occur significantly $\left(a^{3} b=.050\right.$, $p=.002$ ). These results indicate that proactive personality fully mediates the influence of mothers' authoritarian and permissive parenting style on CDSE.

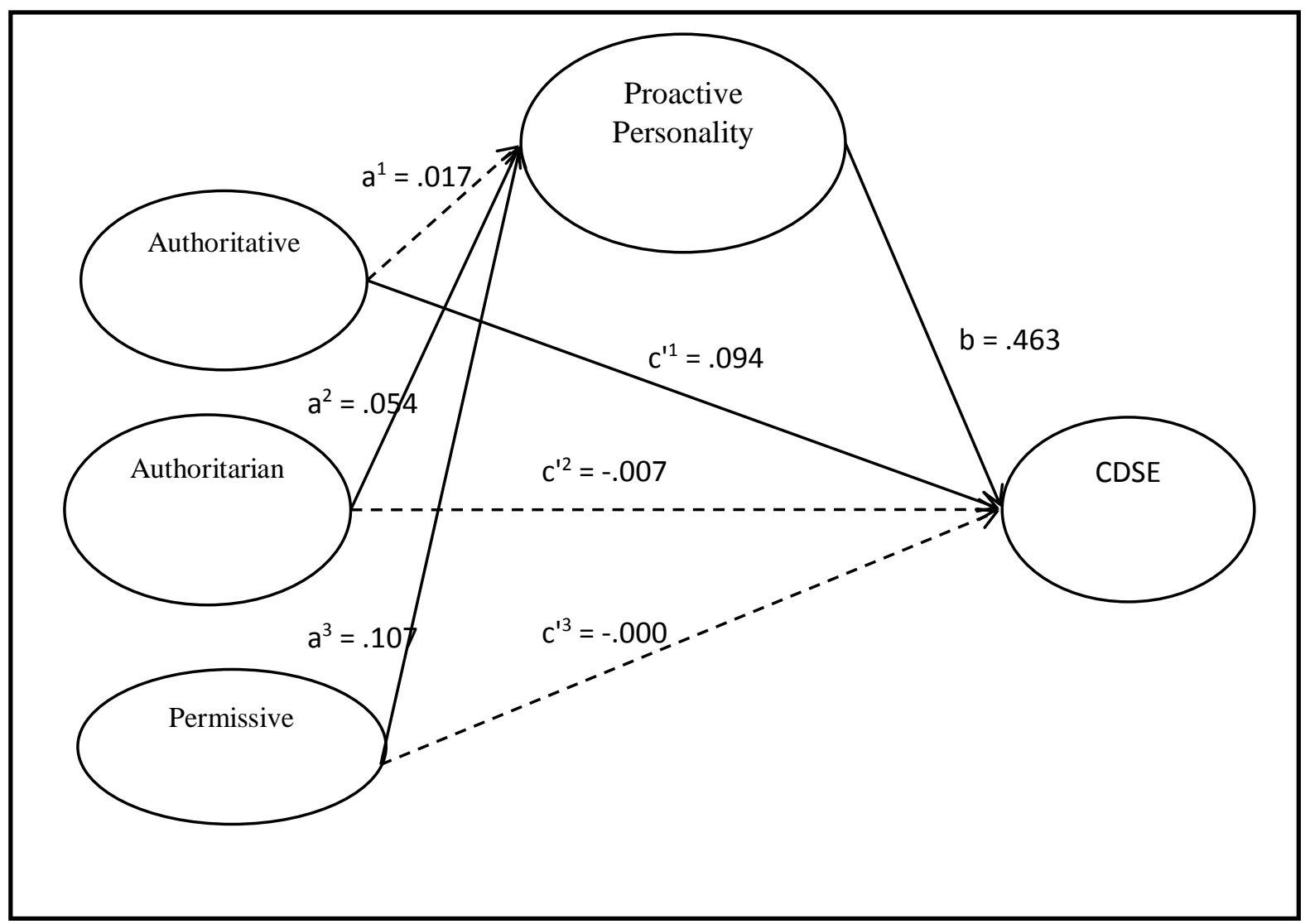

Figure 2. Model of the Effect of Mothers' Parenting Styles on CDSE through Proactive Personality.

\section{Discussion}

Results show that fathers' and mothers' authoritative parenting style influence the CDSE directly (without the proactive personality). This result corroborate the results of the previous study conducted by Sianipar and Sawitri (2015) in Indonesia. Authoritative parents encourage their children to carry out self-exploration and career exploration 
(Kracke, 2002), thereby increasing their ability to assess themselves and gather occupational information which are the competencies needed in CDSE. Papalia, Olds, \& Feldman (2009) also stated that authoritative parents encourage their children to achieve identity status so that they would know their interests or talents which is also needed to be able to make career decisions. This study also found that authoritarian parenting of fathers and mothers can only influence CDSE through a proactive personality. These results indicated that authoritarian parents, both father and mother, can positively influence their child's development, in this case, forming a proactive personality, which consequently increases the CDSE.

As mentioned by Riany et al. (2017) and Bornstein (2012), authoritarian parenting style is considered as the most appropriate to encourage child development in society that holds collectivist cultural values, such as in Indonesia. Even though authoritarian fathers or mothers impose high control on children, the control was perceived as a positive thing by children, namely as a form of care and warmth from father or mother to child (Chao \& Tseng, 2002). Parents, both father and mother, generally also rarely punished or disciplined their child with physical punishment, but with techniques such as shaming (Chao \& Tseng, 2002). Therefore, authoritarian parenting can have a positive effect on children, such as academic achievement and self-regulation of children (Riany et al., 2017), and proactive personality.

Parents with an authoritarian parenting style ensure children to be resilient and ready to face challenging environments while remaining obedient to parents (Chao \& Tseng, 2002). Readiness and resilience are aspects of persistence in achieving desired goals or changes in the concept of proactive personality. In addition, several studies also found that children with authoritarian parenting have a personality that characterizes extraversion personality types, namely assertiveness or self-assertiveness (Baumrind, in Ang \& Goh, 2006), and conscientiousness personality types, namely persistent and independent (Gonzales, Greenwood, \& Hsu, in Ang \& Goh, 2006). These characteristics are also found in individuals who have high proactive personality. Therefore, authoritarian parenting influenced the proactive personality, which in turn influenced their child's CDSE.

The test results also showed that permissive parenting from mothers is having effect on CDSE through the mediation of proactive personality. These results were following previous studies that found that permissive parenting from mothers plays a significant role in the formation of proactive personalities (Preston \& Salim, 2018). To have proactive behavior, children need enough freedom to behave and regulate their activities, which are characterized by permissive parenting. This freedom allows teenagers to do things they want, such as trying things and exploring the environment, so they better see opportunities in their surroundings (Preston \& Salim, 2018). This freedom also allows children to try out a variety of new experiences or activities. As stated earlier, proactive personality is related to extraversion personality types which are characterized by one of them liking new experiences or activities (Bateman \& Crant, 1993). In addition, other researcher also found that permissive parenting produce children who have an openness to experience personality (Weiss, 1996), which is also found to correlate with proactive personality in several studies (Bullock-Yowell, Andrews, \& Buzzetta, 2011; Rogers, Creed, \& Ian Glendon, 2008). Therefore, permissive parenting may form a proactive personality which in turn influences their child's CDSE.

However, the results also showed that permissive parenting from fathers did not affect CDSE through the mediation of proactive personality. The test results showed that permissive parenting from the father do not significantly influence proactive personality and self-efficacy in career decision making. This result is different from the previous results, that mothers' permissive parenting significantly influence proactive personality. 
When discussed in terms of permissive parenting itself, permissive parents do not apply control, direction, and demands the maturity of their children (Baumrind, 2013). This parenting style makes children free but is not directing children behaviors that can encourage the formation of proactive personalities and CDSE.

The different results between fathers' and mothers' permissive parenting style can also be discussed in terms of differences in the role of father and mother in the family or during childcare. Chao and Tseng (2002) stated that in Asian families, fathers tend to act as authority figures who have more power than mothers. Fathers usually show high control, but do not show closeness and affection to children. In addition to being expected to be able to fulfill the responsibilities of providing resources needed by children, fathers are also expected to be able to discipline and control their child's behavior. Based on the expected role of father, the parenting style expected to be adopted by the father is authoritarian or authoritative so that the father can function appropriately in the family and have a significant impact on the child. Therefore, a permissive father in this study is considered as not having a significant effect on CDSE either directly or through the mediation of proactive personality.

Mothers usually show more warmth and supportive to their children (Chao \& Tseng, 2002). The mothers' responsibility for their youths is to provide continuous love and support, support the decision-making process, provide access to resources needed, empathize with the pressures experienced by the youths during the transition to adulthood, and advocate for children's rights (Barnard \& Scholany, 2002). Based on this role, the parenting style expected to be adopted by the mother is permissive parenting.

A study conducted in Shanghai showed that the mothers' warmth was positively associated with self-worth in children and negatively with feelings of loneliness and depression in children (Chao \& Tseng, 2002). Grolnick and Farkas (2002) also noted that most studies saw a significant role for mothers in children's emotional regulation abilities. Children who are able to regulate emotions, not easily depressed, or not easily feeling anxious indicating have a high proactive personality. This condition is in line with the findings that proactive individuals have low level of neuroticism (Fuller \& Marler, 2009; Spitzmuller, Sin, Howe, \& Fatimah, 2015), characterized by having stable emotions, not easily anxious or depressed, and being able to deal with stressful situations. Therefore, permissive mothers can have a positive influenced on the formation of proactive personality which in turn increasing their child's CDSE.

This study implicates that in order to increase senior high school's CDSE, both father and mother should be involved in the process. They can help by giving their children the freedom to explore themselves and various career possibilities while keeping the children supervised and setting boundaries for them. A clear direction is also needed to help children to develop proactive personality and behavior, which was also found to contribute to increasing CDSE.

This research has limitations in describing how the interaction between father and mother in their parenting practices could influence CDSE. In this regard, further research should also examine parents' interactions and their effects on their child career development process.

Future research is also recommended to conduct a longitudinal study to examine the effects of parenting from both parents on children's career development. Papalia et al. (2009) mentioned that the influence of parents on personality and other aspects of children occurs through a prolonged process, ranging from childhood to adulthood. In addition, the career development process also starts from childhood to late adulthood (Patton \& McMahon, 2014). Through longitudinal studies, the influence of parents on children's 
career development will be compared over time, so it might be able to further strengthen the results of this study.

\section{Conclusion}

This study examines the effect of fathers' and mothers' parenting style on CDSE through the mediation of proactive personality in senior high school students. This study finds that, and mothers' authoritarian parenting and mothers' permissive parenting influenced CDSE through a proactive personality. Fathers' authoritative parenting could influence CDSE directly or through the mediation of proactive personality, while mothers' authoritative parenting only could influence CDSE directly. Fathers' permissive parenting style is the only parenting style that does not influence the CDSE both directly and indirectly. Therefore both father and mother need to involve to enhance children's CDSE.

\section{References}

Abubakar, A., Van de Vijver, F. J. R., Suryani, A. O., Handayani, P., \& Pandia, W. S. (2015). Perceptions of Parenting Styles and Their Associations with Mental Health and Life Satisfaction Among Urban Indonesian Adolescents. Journal of Child and Family Studies, 24(9), 2680-2692. https://doi.org/10.1007/s10826-014-0070-x

Anaya, B., \& Pérez-Edgar, K. (2019). Personality development in the context of individual traits and parenting dynamics. New Ideas in Psychology, 53, 37-46. https://doi.org/10.1016/j.newideapsych.2018.03.002

Ang, R. P., \& Goh, D. H. (2006). Authoritarian parenting style in asian societies: A cluster- analytic investigation. Contemporary Family Therapy, 28(1), 131-151. https://doi.org/10.1007/s10591-006-9699-y

Ballout, H. I. (2009). Career commitment and career success: Moderating role of selfefficacy. Career Development International, 14(7), 655-670. https://doi.org/10.1108/13620430911005708

Barnard, K. E. H. of P. V. 1. B. and B. a P., \& Scholany, J. E. (2002). Handbook of Parenting: Vol. 1. Being and Becoming a Parent. In Marc H. Bornstein (Ed.), Handbook of Parenting: Vol. 1. Being and Becoming a Parent (pp. 3 - 26). Mahwah, NJ: Lawrence Erlbaum Associates, Inc.

Bateman, T. S., \& Crant, J. M. (1993). The proactive component of organizational behavior: A measure and correlates. Journal of Organizational Behavior, 14(2), 103118. https://doi.org/10.1002/job.4030140202

Baumrind, D. (2013). Authoritative parenting revisited: History and current status. In Authoritative parenting: Synthesizing nurturance and discipline for optimal child development. (pp. 11-34). American Psychological Association. https://doi.org/10.1037/13948-002

Bolin, J. H. (2014). Hayes, Andrew F. (2013). Introduction to Mediation, Moderation, and Conditional Process Analysis: A Regression-Based Approach. New York, NY: The Guilford Press. Journal of Educational Measurement, 51(3), 335-337. https://doi.org/10.1111/jedm.12050

Bornstein, M. H. (2012). Cultural Approaches to Parenting. Parenting, 12(2-3), 212-221. https://doi.org/10.1080/15295192.2012.683359

Brown, S. D. \& Hirschi, A. (2013). Personality, career development, and occupational attainment. In S. D. Brown \& R. W. Lent (Eds.), Career development and counseling: 
Putting theory and research to work. In Personality, career development, and occupational attainment. In S. D. Brown \& R. W. Lent (Eds.), Career development and counseling: Putting theory and research to work (2nd ed., pp. 299-328). Hoboken, NJ: Wiley \& Sons Inc.

Bullock-Yowell, E., Andrews, L., \& Buzzetta, M. E. (2011). Explaining career decisionmaking self-efficacy: Personality, cognitions, and cultural mistrust. Career Development Quarterly, 59(5), 400-411. https://doi.org/10.1002/j.21610045.2011.tb00967.x

Buri, J. R. (1991). Parental Authority Questionnaire. Journal of Personality Assessment, 57(1), 110-119. https://doi.org/10.1207/s15327752jpa5701_13

Chao, R., \& Tseng, V. (2002). Parenting of Asians. In Handbook of parenting: Social conditions and applied parenting, Vol. 4, 2nd ed. (pp. 59-93). Mahwah, NJ, US: Lawrence Erlbaum Associates Publishers.

Crant, J. M. (1995). The Proactive Personality Scale and Objective Job Performance Among Real Estate Agents. Journal of Applied Psychology, 80(4), 532-537. https://doi.org/10.1037/0021-9010.80.4.532

Crişan, C., \& Turda, S. (2015). The Connection between the Level of Career Indecision and the Perceived Self-efficacy on the Career Decision-making among Teenagers. Procedia - Social and Behavioral Sciences, 209, 154-160. https://doi.org/10.1016/j.sbspro.2015.11.271

Depdiknas. (2004). Pedoman Umum Pengembangan Penilaian (General Guidelines for Educational Assessment). Jakarta.

Di Fabio, A., Palazzeschi, L., Asulin-Peretz, L., \& Gati, I. (2013). Career Indecision Versus Indecisiveness: Associations With Personality Traits and Emotional Intelligence. Journal of Career Assessment, 21(1), 42-56. https://doi.org/10.1177/1069072712454698

Dilas, D. B., Mackie, C., Huang, Y., \& Trines, S. (2019). Education system profiles: Education in Indonesia. WES WENR: World Education News + Reviews. Retrieved September 22, 2019, from https://wenr.wes.org/2019/03/education-in-indonesia-2

Fuller, B., \& Marler, L. E. (2009). Change driven by nature: A meta-analytic review of the proactive personality literature. Journal of Vocational Behavior, 75(3), 329-345. https://doi.org/10.1016/j.jvb.2009.05.008

Grolnick, W. S., \& Farkas, M. (2002). Parenting and the development of children's selfregulation. In Handbook of parenting: Practical issues in parenting, Vol. 5, 2nd ed. (pp. 89-110). Mahwah, NJ, US: Lawrence Erlbaum Associates Publishers.

Gushue, G. V., Scanlan, K. R. L., Pantzer, K. M., \& Clarke, C. P. (2006). The relationship of career decision-making self-efficacy, vocational identity, and career exploration behavior in African American high school students. Journal of Career Development, 33(1), 19-28. https://doi.org/10.1177/0894845305283004

Hou, C., Wu, L., \& Liu, Z. (2014). Effect of Proactive Personality and Decision-Making Self-Efficacy on Career Adaptability Among Chinese Graduates. Social Behavior and Personality: An International Journal, 42(6), 903-912. https://doi.org/10.2224/sbp.2014.42.6.903

Kim, H. S., \& Park, I. J. (2017). Influence of Proactive Personality on Career SelfEfficacy. Journal of Employment Counseling, 54(4), 168-182. https://doi.org/10.1002/joec. 12065

Kracke, B. (2002). The role of personality, parents and peers in adolescents career exploration. Journal of Adolescence, 25(1), 19-30. https://doi.org/10.1006/jado.2001.0446 
Lease, S. H., \& Dahlbeck, D. T. (2009). Parental influences, career decision-making attributions, and self-efficacy: Differences for men and women? Journal of Career Development, 36(2), 95-113. https://doi.org/10.1177/0894845309340794

Lent, R. W., \& Brown, S. D. (2013). Social cognitive model of career self-management: Toward a unifying view of adaptive career behavior across the life span. Journal of Counseling Psychology, 60(4), 557-568. https://doi.org/10.1037/a0033446

Lent, R. W., Ezeofor, I., Morrison, M. A., Penn, L. T., \& Ireland, G. W. (2016). Applying the social cognitive model of career self-management to career exploration and decision-making. Journal of Vocational Behavior, 93, 47-57. https://doi.org/10.1016/j.jvb.2015.12.007

Marcionetti, J., \& Rossier, J. (2017). The Mediating Impact of Parental Support on the Relationship Between Personality and Career Indecision in Adolescents. Journal of Career Assessment, 25(4), 601-615. https://doi.org/10.1177/1069072716652890

McKinney, C., \& Renk, K. (2008). Differential parenting between mothers and fathers: Implications for late adolescents. Journal of Family Issues, 29(6), 806-827. https://doi.org/10.1177/0192513X07311222

Papalia, D. E., Olds, S. W., \& Feldman, R. D. (2009). Human development. New York, NY: McGraw-Hill.

Park, Y. S., Kim, B. S. K., Chiang, J., \& Ju, C. M. (2010). Acculturation, enculturation, parental adherence to asian cultural values, parenting styles, and family conflict among asian american college students. Asian American Journal of Psychology, 1(1), 67-79. https://doi.org/10.1037/a0018961

Patton, W., \& McMahon, M. (2014). Career Development and Systems Theory: Connecting Theory and Practice. New Horizons in Adult Education \& Human Resource Development (Vol. 23). https://doi.org/10.1017/CBO9781107415324.004

Penn, L. T., \& Lent, R. W. (2016). Testing the joint roles of career decision self-efficacy and personality traits in the prediction of career indecision. Doctoral Dissertation. University of Maryland, College Park. https://doi.org/10.1192/bjp.112.483.211-a

Preston, M., \& Salim, R.-M. A. (2018). Pengaruh pola asuh orangtua terhadap kepribadian proaktif remaja (The effect of parenting style on proactive personality in Adolescent). Unpublished Manuscript.

Riany, Y. E., Meredith, P., \& Cuskelly, M. (2017). Understanding the Influence of Traditional Cultural Values on Indonesian Parenting. Marriage and Family Review, 53(3), 207-226. https://doi.org/10.1080/01494929.2016.1157561

Rogers, M. E., \& Creed, P. A. (2011). A longitudinal examination of adolescent career planning and exploration using a social cognitive career theory framework. Journal of Adolescence, 34(1), 163-172. https://doi.org/10.1016/j.adolescence.2009.12.010

Rogers, M. E., Creed, P. A., \& Ian Glendon, A. (2008). The role of personality in adolescent career planning and exploration: A social cognitive perspective. Journal of Vocational Behavior, 73(1), 132-142. https://doi.org/10.1016/j.jvb.2008.02.002

Sawitri, D. (2009). Pengaruh status identitas dan efikasi diri keputusan karier terhadap keraguan mengambil keputusan karier pada mahasiswa tahun pertama di Universitas Diponegoro (The influence of identity status and career decision self efficacy on career decision doubt am. Junal Psikologi Undip.

Seibert, S. E., Grant, J. M., \& Kraimer, M. L. (1999). Proactive personality and career success. Journal of Applied Psychology, 84(3), 416-426. https://doi.org/10.1037/0021-9010.84.3.416

Sianipar, C. S., \& Sawitri, D. R. (2015). Pola asuh otoritatif orang tua dan efikasi diri dalam mengambil keputusan karier pada mahasiswa tahun pertama (Authoritative 
parenting and career decision self efficacy among the first year undergraduate students). Jurnal Empati, 4(4), 1-7.

Sovet, L., \& Metz, A. J. (2014). Parenting styles and career decision-making among French and Korean adolescents. Journal of Vocational Behavior, 84(3), 345-355. https://doi.org/10.1016/j.jvb.2014.02.002

Spitzmuller, M., Sin, H. P., Howe, M., \& Fatimah, S. (2015). Investigating the Uniqueness and Usefulness of Proactive Personality in Organizational Research: A Meta-Analytic Review. Human Performance, 28(4), 351-379. https://doi.org/10.1080/08959285.2015.1021041

Taylor, K. M., \& Betz, N. E. (2006). Manual for the career decision self-efficacy scale and CDSE-Short Form. Unpublished Material. Retrieved from http://www.hkcss.org.hk/uploadfileMgnt/0_201443011559.pdf\%0Ahttps://doi.org/10. 1016/0001-8791(83)90006-4

Weiss, L. H. (1996). The Relationship between Parenting Types and Older Adolescents. Child Development, 67(5), 2101. https://doi.org/10.2307/1131612 